\title{
Impact of climate change on hydropower potential of the Lagdo dam, Benue River Basin, Northern Cameroon
}

\author{
Rodric M. Nonki ${ }^{1}$, André Lenouo ${ }^{2}$, Clément Tchawoua ${ }^{3}$, Christopher J. Lennard ${ }^{4}$, and \\ Ernest Amoussou ${ }^{5}$ \\ ${ }^{1}$ Laboratory for Environmental Modeling and Atmospheric Physics, Department of Physics, Faculty of \\ Sciences, University of Yaounde, P.O. Box 812, Yaounde, Cameroon \\ ${ }^{2}$ Department of Physics, Faculty of Science, University of Douala, Douala, Cameroon \\ ${ }^{3}$ Laboratory of Mechanics, Department of Physics, Faculty of Sciences, \\ University of Yaounde, Yaounde, Cameroon \\ ${ }^{4}$ Climate System Analysis Group, University of Cape Town, Cape Town, South Africa \\ ${ }^{5}$ Laboratoire Pierre Pagney: Climat, Eau, Ecosystème et Développement (LACEEDE), \\ University of Parakou, Parakou, Benin \\ Correspondence: Rodric M. Nonki (norome31@yahoo.fr) \\ Published: 16 November 2021
}

\begin{abstract}
Nowadays, special attention is paid to hydroelectric production because it is an efficient, reliable, and renewable source of energy, especially in developing countries like Cameroon, where hydropower potential is the main source of electricity production. It also represents a useful tool to reduce the atmospheric greenhouse gas concentrations caused by human activities. However, it is the most sensitive industry to global warming, mainly because climate change will directly affect the quality, quantity of water resources (streamflow and runoff), which are the important drivers of hydropower potential. This study examined the response of hydropower potential to climate change on the Lagdo dam located in the Benue River Basin, Northern Cameroon. Hydropower potential was computed based on streamflow simulated using HBV-Light hydrological model with dynamically downscaled temperature and precipitation from the regional climate model REMO. These data were obtained using the boundary conditions of two general circulation models (GCMs): the Europe-wide Consortium Earth System Model (EC-Earth) and the Max Planck Institute-Earth System Model (MPI-ESM) under three Representative Concentrations Pathways (RCP2.6, RCP4.5 and RCP8.5). The results suggest that, the combination of decreased precipitation and streamflow, increased PET will negatively impact the hydropower potential in the Lagdo dam under climate change scenarios, models and future periods.
\end{abstract}

\section{Introduction}

The Benue River Basin (BRB) is the Cameroonian part of the Niger River Basin (NRB) and occupies $4.4 \%$ of the overall basin. The BRB lies between latitude 7 and $11^{\circ} \mathrm{N}$ and longitude 12 and $16^{\circ} \mathrm{E}$ (Fig. 1), and constitutes the second-largest river in Cameroon. It is the only perennial river in northern Cameroon and the neighboring areas where most of the rivers are seasonal (Olivry, 1986). The basin provides huge potential for development of water resources services that include hydropower, navigation and irrigation. In 1982, the Lagdo dam was built. The dam is $308 \mathrm{~m}$ long, $40 \mathrm{~m}$ in height and $9 \mathrm{~m}$ thick with an area of $586 \mathrm{~km}^{2}$. It has an installed capacity of $72 \mathrm{MW}$ and the entire northern part of Cameroon is currently supplied with electricity from Lagdo. Given its capacity on hydropower, there is a proposal to increase hydropower and irrigation capacity of the Lagdo dam with the objective to supply electricity to other countries such as the Chad Republic, the northern Nigeria and part of the Central African Republic (IRAP, 2015).

However, BRB experienced water related disasters such as floods and droughts (Molua and Lambi, 2006; Sighom- 


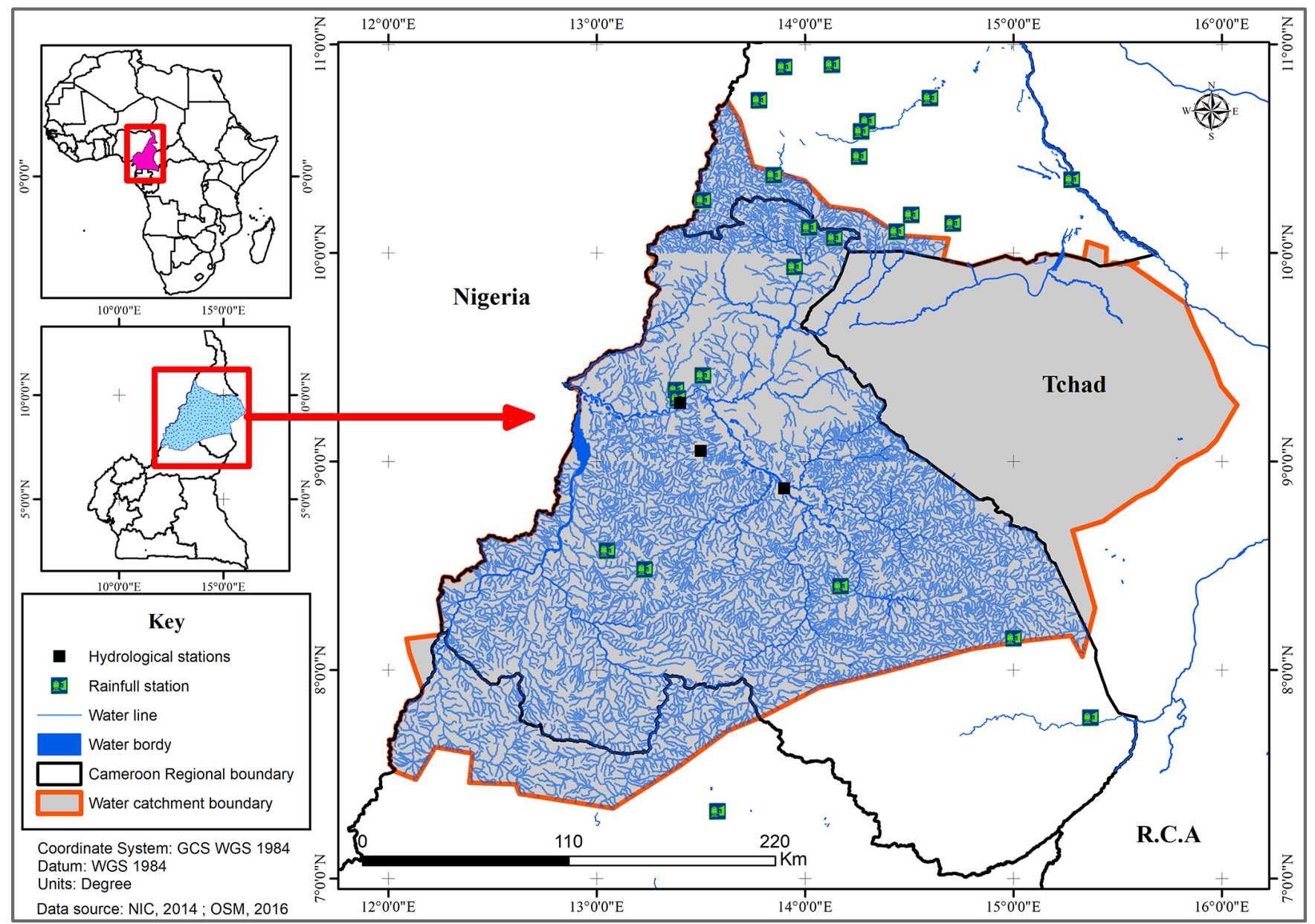

Figure 1. Study catchment: basin drainage area and rainfall and hydrological stations.

nou et al., 2013). In addition, recent studies showed the negative trend on rainfall and positive trend on temperature in the Northern Cameroon (Cheo et al., 2013; Dassou, 2019), while another studies revealed the increase of drought magnitude and intensity in the Northern Cameroon and in NRB (Guenang and Mkankam, 2014; Oguntunde et al., 2018) under changing environmental conditions. Nonki et al. (2019) also found that the BRB will move to extreme environmental drier conditions due to a decrease in excess water and an increase in evaporative demand under climate change. As key components of the hydrological cycle, any change in climate that affects rainfall and temperature will have proportionate impacts on the hydrological system in the area especially at the basin scale. According to Pal and Al-Tabbaa (2011), any change in the hydrological cycle due to global warming is likely to affect the distribution of water resources and consequently agriculture and hydropower production in the region as well as the availability and quality of freshwater. Therefore, climate change impact assessment on hydropower potential of this important watershed is highly important to sup- port projects and develop new strategies for adaptation in this watershed.

The only existing study on this watershed (Grijsen et al., 2014) was based on General Climate Models (GCMs). According to Chou et al. (2014), climate change impact assessment at the regional and local scale needs higher resolution spatial data and GCMs with a coarse horizontal grid resolution do not capture these local and regional effects (Deb et al., 2015). In this context, the COordinated Regional climate Downscaling EXperiment project (CORDEX; Giorgi et al., 2009; http://www.cordex.org, last access: 17 October 2021) equipped African continent with many downscaled climate data from regional climate models (RCMs) that have downscaled many GCMs from phase 5 of the Coupled Model Intercomparison Project (CMIP5). Although several studies have assessed the impacts of $\mathrm{CC}$ on hydropower potential around the World and especially in Africa by using downscaled climate data, none of the above-mentioned studies assessed the climate change impacts on hydropower potential on BRB. Then, this study uses the downscaled precipitation 
and temperature data to assess the impact of climate change on hydropower potential of the Lagdo dam, BRB.

\section{Materials and methods}

\subsection{HBV-Light hydrological model and data}

The HBV-Light hydrological model (Seibert, 2005) used in this study is the modified version of HBV (Hydrologiska Byråns Vattenavdelning) hydrological model, initially developed in the Swedish Meteorological and Hydrological Institute (SMHI) by Bergstrom and Forman (1973). It is a conceptual-lumped model working in the daily time step and simulating discharges using daily precipitation and PET as input. This model was chosen due to his flexibility and robustness in simulating discharge in African context (Kwakye and Bardossy, 2020; Nonki et al., 2021a). More explanations of the model structure can be found in different studies (Seibert, 2005; Nonki et al., 2019, 2021b).

Daily measured weather data (precipitation) and potential evapotranspiration (PET) computed with Penman formula (Penman, 1948) from 1961-1978, used to calibrate and validate the model was obtained from the Direction of the National Meteorology of Cameroon (DNM), while the daily streamflow data measured at the available hydro-metric stations (Riao) located in the basin, were obtained from the Hydrosciences Montpellier - Système d'Informations Environnementales database (SIEREM; Boyer et al., 2006; http: //hydrosciences.fr/sierem, last access: 17 October 2021).

In order to predict the climate change impact on hydropower potential, historical and projected scenarios of dynamically downscaled temperature and precipitation from the REMO regional climate model (RCM) forced by the boundary conditions data of the Europe-wide Consortium Earth System Model (EC-ESM) and the Max Planck Institute-Earth System Model (MPI-ESM) general circulation models (GCMs). REMO is integrated over a continuous period of 151 years, from January 1950 to December 2100 with 31 vertical levels and a horizontal resolution of $50 \mathrm{~km}\left(0.44^{\circ}\right)$. REMO showed a strong ability to simulate the present climate in Central Africa in general (FotsoNguemo et al., 2017) and in the Northern Cameroon in particular (Nonki et al., 2019).

\subsection{Calibration, validation and HBV-Light model performance assessment}

In this study, the split sample test (Klemeš, 1986) and the Monte-Carlo simulations (MCS) (Robert and Casella, 2013) were used for model calibration and parameter optimization. Our data time series were separated into two sub-periods (1961-1970 for calibration and 1971-1979 for validation).

The model performance was then assessed by using different statistical techniques such as Nash and Sutcliffe Efficiency (NSE), Percent Bias (PBIAS), the ratio of the root mean square error (RMSE) and standard deviation of measured data (STDEVobs) (RSR) and the coefficient of determination $\left(R^{2}\right)$. More details and descriptions of those statistical techniques can be found in Moriasi et al. (2007).

\subsection{Assessment of the hydropower potential}

The hydropower potential is the total energy from all natural runoff at stream gradient over the entire domain. It is achieved by converting the potential and kinetic energy of the water into electrical energy by electro-mechanical means (Turbines and Generators). Hydropower potential is estimated based on the streamflow, hydraulic head i.e. elevation gradient in this case and the total plant efficiency, as shown in the following equation (de Oliveira et al., 2017):

$N_{\mathrm{p}}=Q \times H \times \rho_{\mathrm{w}} \times g \times \eta$

where $N_{\mathrm{p}}$ is the hydropower potential $(W) ; Q$ is the stream flow $\left(\mathrm{m}^{3} \mathrm{~s}^{-1}\right), H$ is the water head of the turbine $(\mathrm{m}), \rho_{\mathrm{w}}$ is the water density $\left(\mathrm{kg} / \mathrm{m}^{3}\right), g$ is the gravitational acceleration and $\eta$ is the total efficiency of the turbine (\%).

Through that equation, reference and future streamflow simulated with the calibrated HBV-Light model were used to estimate the reference and future hydropower potential. The potential changes of hydropower potential by the near (20412065) and late (2071-2095) of the twenty-first century under RCPs 2.6, 4.5 and 8.5 relative to the baseline period (19812005).

\section{Results and discussion}

\subsection{Hydrological model evaluation}

Figure 2 shows the measured and modeled hydrographs as well as the flow duration curves at the Riao outlet during the calibration and validation periods. The model reproduces the timing and magnitude of the observed streamflow well although some small bias (PBIAS less than $15 \%$ ). The flow duration curves also revealed that the model reproduces the low flows more accurately than the high flows. Based on the statistical criteria analysis, the model performance is very good according to Moriasi et al. (2007) classification (with NSE of 0.86 and 0.78 , RSR of 0.38 and 0.47 obtained during the calibration and validation periods respectively). There is also a strong relationship between modeled and observed streamflow (with $R^{2}=0.90$ ).

\subsection{Projected changes in monthly, seasonal and annual hydropower potential}

Figure 3 shows relative changes in monthly, seasonal and annual hydropower potential under the scenarios, models and time periods. The impact of climate change on hydropower potential is similar to the pattern of changes in streamflow (Nonki et al., 2019). In general, hydropower potential of the 
(a)
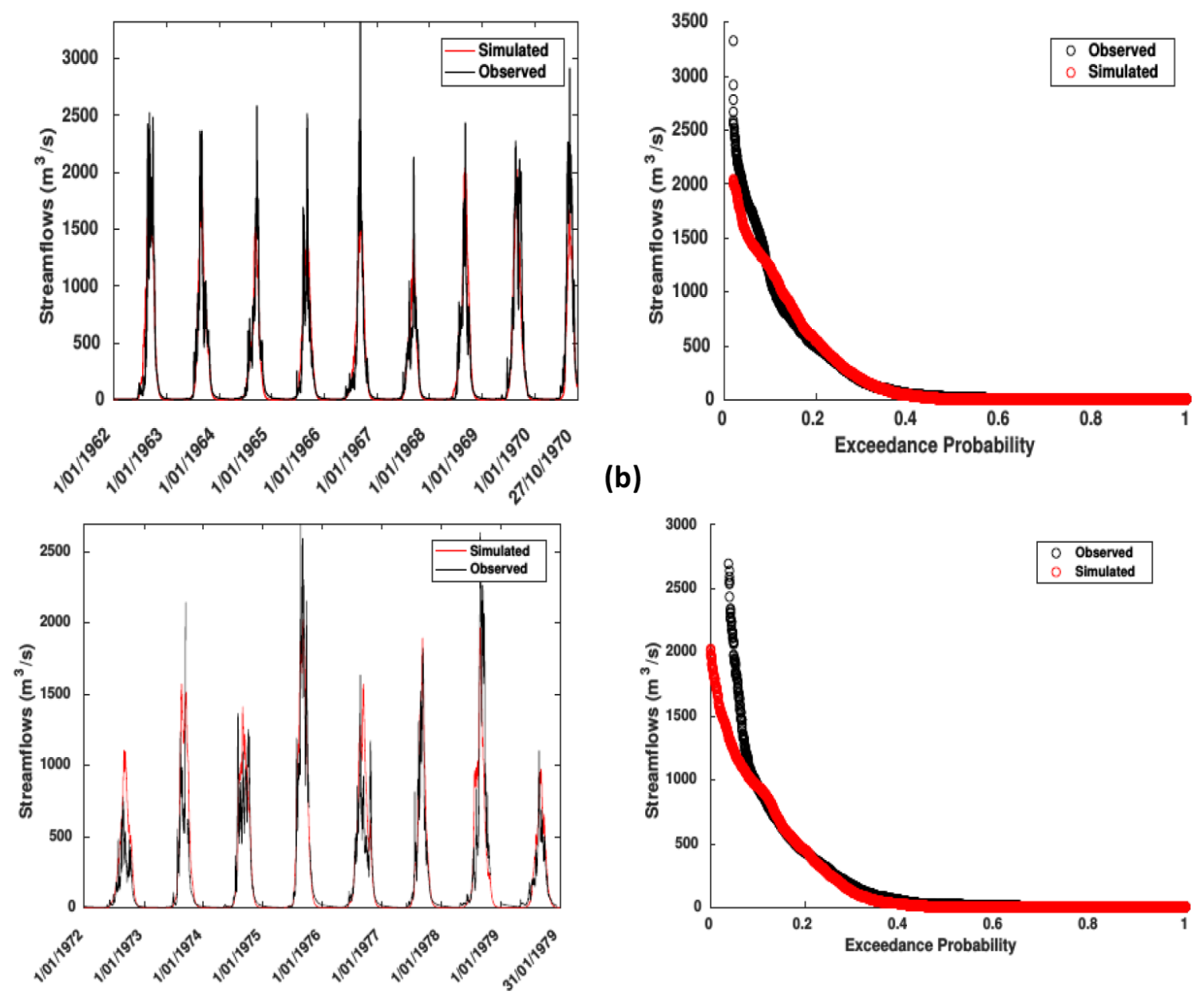

(b)

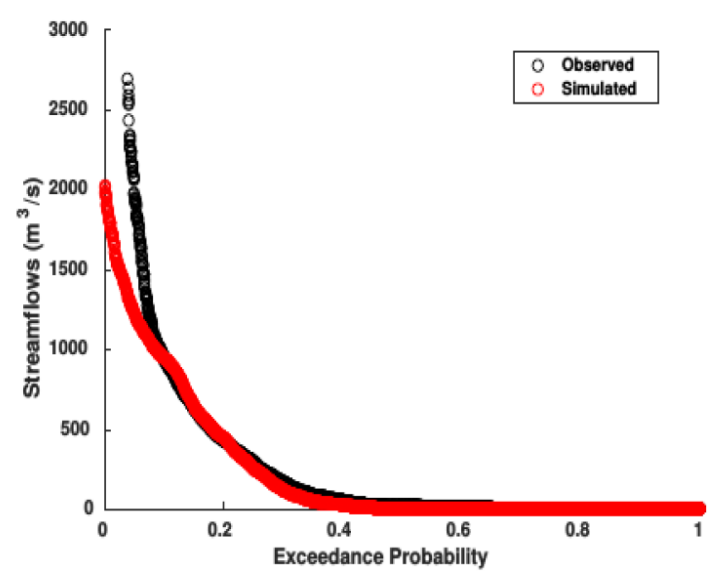

Figure 2. Comparison between observed and simulated hydrographs and flow duration curves at the Riao outlet during the calibration period (a) and validation period (b).

Lagdo dam is projected to decrease. During September, the signal is strong under all scenarios, models and time periods, with the maximum decrease observed in the REMOMPI combination during the late of the twenty-first century. The dry months do not exhibit a change signal which can be explained by absence of rainfall, thus very few streamflow. The seasonal and annual hydropower potential will decrease under both scenarios and time periods. The magnitude of the signal should vary according to the scenarios and time periods. This finding is consistent with that of Grijsen (2014). The similar negative trend was also reported in several studies in African catchments (Cole et al., 2014; Lumbroso et al., 2015; Falchetta et al., 2019).

\section{Conclusions}

The main focus of this work was to evaluate the influence of the projected temperature and precipitation change on hydropower potential of the Lagdo dam in the BRB, Northern
Cameroon. Streamflow used to compute the hydropower potential was produced by coupling dynamically downscaled precipitation and temperature from the REMO model and the HBV-Light hydrological model under three (GHGs) concentration scenarios (RCP2.6, RCP4.5, and RCP8.5) during the future and baseline periods. The results showed that the optimized model parameters highly performed the HBV-Light model in the BRB during the calibration and validation stage. Based on climate scenarios, models and future time periods, the hydropower potential of the Lagdo dam will decrease, which is the result of the reduced precipitation and increase of PET, thus decrease in streamflow in the BRB. One major caveat of this study is the use of only one RCM with two GCMs models. Therefore, further works with a multi-model ensemble from CORDEX-Africa matrix are needed to quantify the range of uncertainty in this signal. 
$\mathrm{RCP} 2.6$

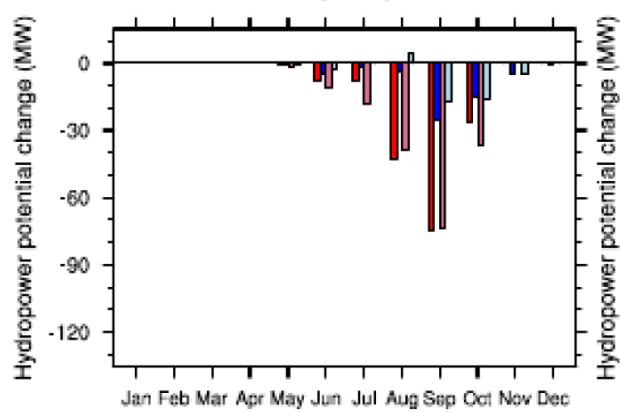

$\operatorname{RCP} 2.6$

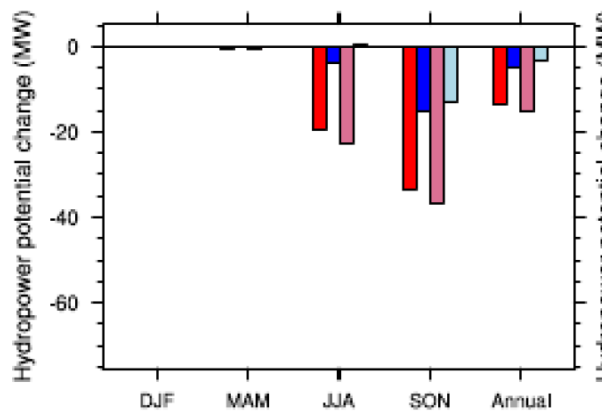

REMO-EC(2041-2065)
$\mathrm{RCP} 4.5$

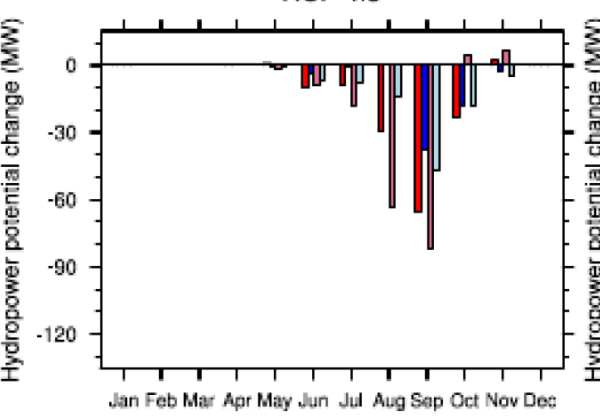

RCP 4.5

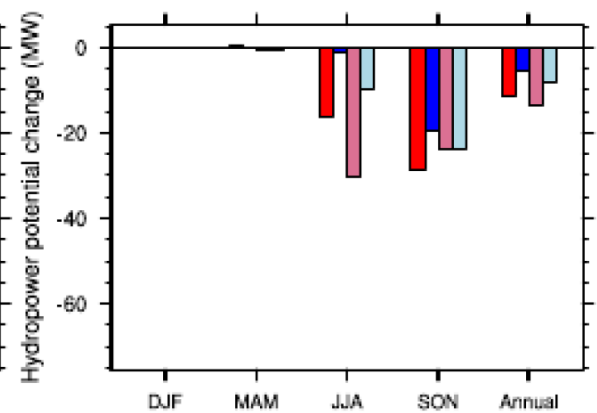

REMO-MPI(2041-2065)

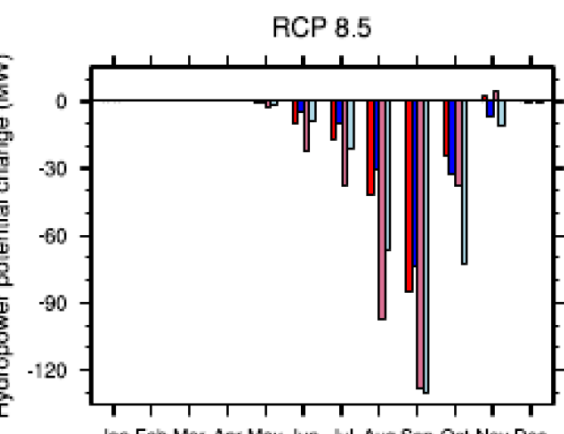

Jan Feb Mar Apr May dun dul Aug Sep Oci Nov Dec

$\operatorname{RCP} 8.5$

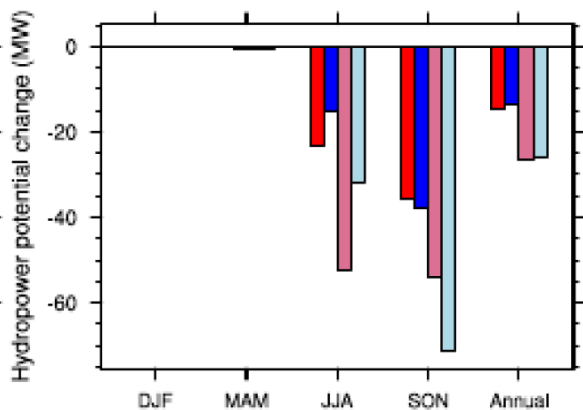

REMO-MPI(2071-2095)

Figure 3. Projected monthly (top), seasonal and annual (bottom) changes in hydropower potential of the Lagdo dam under the three scenarios (RCP2.6, RCP4.5, RCP8.5) for the two future periods (2041-2065 and 2071-2095) relative to the baseline period (1981-2005).

Data availability. Meteorological and hydrological data are the properties of the Direction of the National Meteorology of Cameroon (DNM) and the SIEREM/HSM database respectively.

Author contributions. RMN: Conceptualization, Methodology, Software, Formal analysis, Validation, Writing - original draft. AL: Conceptualization, Software, Writing - original draft, Supervision. CT: Conceptualization, Methodology, Validation, Writing - review and editing. CJL: Data curation, investigation Visualization, Writing - review and editing. EA: Writing - review and editing.

Competing interests. The contact author has declared that neither they nor their co-authors have any competing interests.

Disclaimer. Publisher's note: Copernicus Publications remains neutral with regard to jurisdictional claims in published maps and institutional affiliations.

Special issue statement. This article is part of the special issue "Hydrology of Large River Basins of Africa". It is a result of the 4th International Conference on the "Hydrology of the Great Rivers of Africa", Cotonou, Benin, 13-20 November 2021.
Acknowledgements. The authors would like to thank the organizers of the 4th Conference on the hydrology of African Rivers, the data providers and the anonymous reviewers of this manuscript. We also thank the IAHS through SYSTA award for funding the first author to attend this conference.

\section{References}

Bergstrom, S. and Forman, A.: Development of a conceptual deterministic rainfall-runoff model, Nordic Hydrol., 4, 240-253, 1973.

Boyer, J. F., Dieulin, C., Rouche, N., CRES, A., Servat, E., Paturel, J. E., and Mahé, G.: SIEREM: an environmental information system for water resources, IAHS Publ., 308, 19-25, 2006.

Cheo, A. E., Voigt, H. J., and Mbua, R. L.: Vulnerability of water resources in northern Cameroon in the context of climate change, Environ. Earth Sci., 70, 1211-1217, https://doi.org/10.1007/s12665-012-2207-9, 2013.

Chou, S. C., Lyra, A., Mourão, C., Dereczynski, C., Pilotto, I., Gomes, J., Bustamante, J., Tavares, P., Silva, A., Rodrigues, D., Campos, D., Chagas, D., Sueiro, G., Siqueira, G., and Marengo, J.: Assessment of climate change over South America under RCP4.5 and 8.5 downscaling scenarios, Am. J. Clim. Change, 3, 512-525, 2014

Cole, M. A., Elliott, R. J., and Strobl, E.: Climate change, hydrodependency, and the African dam boom, World Dev., 60, 84-98, 2014. 
Dassou, E. F.: Impact de la variabilité climatique sur la réponse hydrologique du bassin versant supérieur de la Bénoué (NordCameroun), Thèse de Doctorat/PhD, Université de Maroua, 332 pp., 2019.

Deb, D., Butcher, J., and Srinivasan, R.: Projected hydrologic changes under mid-21st century climatic conditions in a subarctic watershed, Water Resour. Manag., 29, 1467-1487, 2015.

de Oliveira, V. A., de Mello, C. R., Viola, M. R., and Srinivasan, R.: Assessment of climate change impacts on streamflow and hydropower potential in the headwater region of the Grande river basin, Southeastern Brazil, Int. J. Climatol., 37, 5005-5023, https://doi.org/10.1002/joc.5138, 2017.

Falchetta, G., Gernaat, D. E., Hunt, J., and Sterl, S.: Hydropower dependency and climate change in sub-Saharan Africa: A nexus framework and evidence-based review, J. Clean. Prod., 231, 1399-1417, https://doi.org/10.1016/j.jclepro.2019.05.263, 2019.

Fotso-Nguemo, T. C., Vondou, D. A., Tchawoua, C., and Haensler, A.: Assessment of simulated rainfall and temperature from the regional climate model REMO and future changes over Central Africa, Clim. Dynam., 48, 3685-3705, https://doi.org/10.1007/s00382-016-3294-1, 2017.

Giorgi, F., Jones, C., and Asrar, G. R.: Addressing climate information needs at the regional level: the cordex framework, World Meteorol. Org. (WMO) Bull., 58, 175-182, 2009.

Guenang, G. M. and Mkankam, K. F.: Computation of the Standardized Precipitation Index (SPI) and its use to assess drought occurrences in Cameroon over recent decades, J. Appl. Meteorol. Climatol., 53, 2310-2324, https://doi.org/10.1175/JAMC-D14-0032.1, 2014.

Grijsen, J.: Understanding the impact of climate change on hydropower: the case of Cameroon, World bank Report, Washington, DC, 2014.

IRAP (International Rivers Africa Program): Hydropower in Africa: African Dams Briefing, 1250 Pretorius street, Suite G9 Ground Floor, East wing Pro Equity Court, Hatfield 00083, Pretoria, 2015.

Klemeš, V.: Operational testing of hydrologic simulation models, Hydrol. Sci. J., 31, 13-24, 1986.

Kwakye, S. O. and Bardossy, A.: Hydrological modelling in data scarce catchments: black Volta basin in West Africa, SN Appl. Sci., 2, 1-19, https://doi.org/10.1007/s42452-020-2454-4, 2020.

Lumbroso, D. M., Woolhouse, G., and Jones, L.: A review of the consideration of climate change in the planning of hydropower schemes in sub-Saharan Africa, Climatic Change, 133, 621-633, 2015.

Molua, E. L. and Lambi, C. M.: Climate, hydrology and water resources in Cameroon, Discussion Paper No. 33 Special Series on Climate Change and Agriculture in Africa, University of Pretoria, Pretoria: Centre for Environmental Economics and Policy in Africa [CEEPA], 2006.
Moriasi, D. N., Arnold, J. G., Van Liew, M. W., Bingner, R. L., Harmel, R. D., and Veith, T. L.: Model evaluation guidelines for systematic quantification of accuracy in watershed simulations, Trans. ASABE, 50, 885-900, https://doi.org/10.13031/2013.23153, 2007.

Nonki, R. M., Lenouo, A., Lennard, C. J., and Tchawoua, C.: Assessing climate change impacts on water resources in the Benue River Basin, Northern Cameroon, Environ. Earth Sci., 78, 1-18, https://doi.org/10.1007/s12665-019-8614-4, 2019.

Nonki, R. M., Lenouo, A., Lennard, C. J., Tshimanga, R. M., and Tchawoua, C.: Comparison between dynamic and static sensitivity analysis approaches for impact assessment of different potential evapotranspiration methods on hydrological models' performance, J. Hydrometeor., 22, 2713-2730, 2021a.

Nonki, R. M., Lenouo, A., Tshimanga, R. M., Donfack, F. C., and Tchawoua, C.: Performance assessment and uncertainty prediction of a daily time-step HBV-Light rainfall-runoff model for the Upper Benue River Basin, Northern Cameroon, J. Hydrol., 36, 100849, https://doi.org/10.1016/j.ejrh.2021.100849, 2021b.

Oguntunde, P. G., Lischeid, G., and Abiodun, B. J.: Impacts of climate variability and change on drought characteristics in the Niger River basin, West Africa, Stoch. Environ. Res. Risk Assess., 32, 1017-1034, https://doi.org/10.1007/s00477-017-1484y, 2018.

Olivry, J. C.: Fleuves et rivières du Cameroun, Monographies hydrologiques ORSTOM, Thèse de Doctorat es Sciences, Université de Montpellier, 1986.

Pal, I. and Al-Tabbaa, A.: Regional changes of the severities of meteorological droughts and floods in India, J. Geogr. Sci., 21, 195206, https://doi.org/10.1007/s11442-011-0838-5, 2011.

Penman, H. L.: Natural evaporation from open water, bare soil and grass, Proc. Roy Soc. A, 193, 120-145, https://doi.org/10.1098/rspa.1948.0037, 1948.

Robert, C. and Casella, G.: Monte Carlo statistical methods, Springer Science \& Business Media, New York, 2013.

Seibert, J.: HBV-Light version 2, user's manual, Department of Earth Sciences, Uppsala University, Uppsala, 2005.

Sighomnou, D., Descroix, L., Genthon, P., Mahé, G., Moussa, B. I., Gautier, E., Mamadou, I., Vandervaere, J. P., Bachir, T., Coulibaly, B., Rajot, J. L., Issa, M. O., Abdou, M. M., Dessay, N., Delaitre, E., Maiga, F. O., Diedhiou, A., Panthou, G., Vischel, T., Yacouba, H., Karambiri, H., Paturel, J. E., Diello, P., Mougin, E., Kergoat, L., Hiernaux, P.: The Niger River Niamey flood of 2012: The paroxysm of the Sahelian paradox?, Secheresse, 24, 3-13, 2013. 